\title{
Erratum to: Opening Skinner's Box: an Introduction
}

\section{Matthew P. Normand}

Published online: 13 November 2014

(C) Association for Behavior Analysis International 2014

\author{
Erratum to: BEHAV ANALYST \\ DOI 10.1007/s40614-014-0016-Z
}

The original version of the article indicated that the papers in the special section grew out of a panel discussion at the 2014 meeting of the Association for Behavior Analysis, International. The panel discussion actually took place at the 2013 meeting.

The online version of the original article can be found at http://dx.doi.org/10.1007/s40614-014-0016-Z.

M. P. Normand $(\bowtie)$

Department of Psychology, University of the Pacific, 3601 Pacific Avenue, Stockton, CA 95211, USA e-mail: mnormand@pacific.edu 